\title{
A Major Unconformity Between Permian and Triassic Strata at Cape Kekurnoi, Alaska Peninsula: Old and New Observations on Stratigraphy and Hydrocarbon Potential
}

\author{
By Robert B. Blodgett ${ }^{1}$ and Bryan Sralla ${ }^{2}$
}

\section{Abstract}

A major angular unconformity separates carbonates and shales of the Upper Triassic Kamishak Formation from an underlying unnamed sequence of Permian agglomerate, volcaniclastic rocks (sandstone), and limestone near Puale Bay on the Alaska Peninsula. For the first time, we photographically document the angular unconformity in outcrop, as clearly exposed in a seacliff $\sim 1.3 \mathrm{mi}(2.1 \mathrm{~km})$ west of Cape Kekurnoi in the Karluk C-4 and C-5 1:63,360-scale quadrangles. This unconformity is also documented by examination of core chips, ditch cuttings, and (or) open-hole electrical logs in two deep oil-and-gas-exploration wells (Humble Oil \& Refining Co.'s Bear Creek No. 1 and Standard Oil Co. of California's Grammer No. 1) drilled along the Alaska Peninsula southwest of Puale Bay. A third well (Richfield Oil Corp.'s Wide Bay Unit No. 1), south of and structurally on trend with the other two wells, probed deeply into the Paleozoic basement, but Triassic strata are absent, owing to either a major unconformity or a large fault.

Here we briefly review current and newly acquired data on Permian and Triassic rocks of the Puale Bay-Becharof Lake-Wide Bay area on the basis of an examination of surface and subsurface materials. The resulting reinterpretation of the Permian and Triassic stratigraphy has important economic ramifications for oil and gas exploration on the Alaska Peninsula and in the Cook Inlet basin. We also present a history of petroleum exploration targeting Upper Triassic reservoirs in the region.

\section{Introduction and Historical Background}

The Alaska Peninsula, specifically the onshore area between Puale Bay (known before the 1950s as Cold Bay) and Wide Bay (fig. 1), has been subjected to extensive geologic

${ }^{1}$ Contract employee.

${ }^{2}$ XTO Energy, Inc., Fort Worth, Tex. reconnaissance and oil and gas prospecting dating back to the early 1900s. The impetus for early geologic interest came from the recognition of several broad surface anticlines, along with active oil and gas seeps emerging from Jurassic sandstone and siltstone cropping out along the axis of the anticlines.

The internal company report by Hanna and others (1937) makes it apparent that the thick succession of Upper Triassic carbonates exposed between Puale and Alinchak Bays on the Pacific side of the Alaska Peninsula, directly across Shelikof Strait from Kodiak Island, Alaska (fig. 1), was of primary interest early on as an exploration target. Work by the Standard Oil Co. of California during the 1930s, along with encouragement by the famous Alaska oil prospector Earl Grammer, resulted in the drilling of Grammer No. 1 well (spudded in 1938 and completed in 1940) along the axis of the Salmon/Bear Creek anticline (fig. 1) to a depth of 7,596 ft $(2,315 \mathrm{~m})$ — at that time, the deepest well drilled in Alaska. No commercial production was obtained despite the occurrence of numerous oil and gas shows, with several cores bleeding live oil and bubbling gas. Furthermore, well reports indicate that Standard could not conclusively determine whether or not the well had, in fact, penetrated Triassic strata. Even after this setback, investigations continued sporadically during the years surrounding World War II.

In 1953, Shell Oil Co. engaged in an initial reconnaissance around Puale Bay, the Iniskin Peninsula, and the Kenai Peninsula, conducted by district geologist R.L. Blocher under the direction of senior Shell geologist Max Birkhauser. For the next three summer seasons, Shell operated four field parties on the Alaska Peninsula, covering the area on horseback for the first 2 years, then by helicopter during the third and forth seasons. Detailed structural mapping of the Bear Creek anticline was carried out by party chief Herb Mann, while Jim Kennell and Mack Robinson mapped the Triassic and Permian rocks around Cape Kekurnoi in fine detail, using a boat. Shell's carbonate specialist James Lee Wilson, who spent a week at Cape Kekurnoi studying the outcrops with Herb Mann, proffered the opinion that the lower part of the Upper Triassic "reef" limestone constituted an encouraging petroleum-reservoir target. Shell's recognition of the Triassic carbonates, in combination with its geologists' mapping efforts indicating a large closed- 


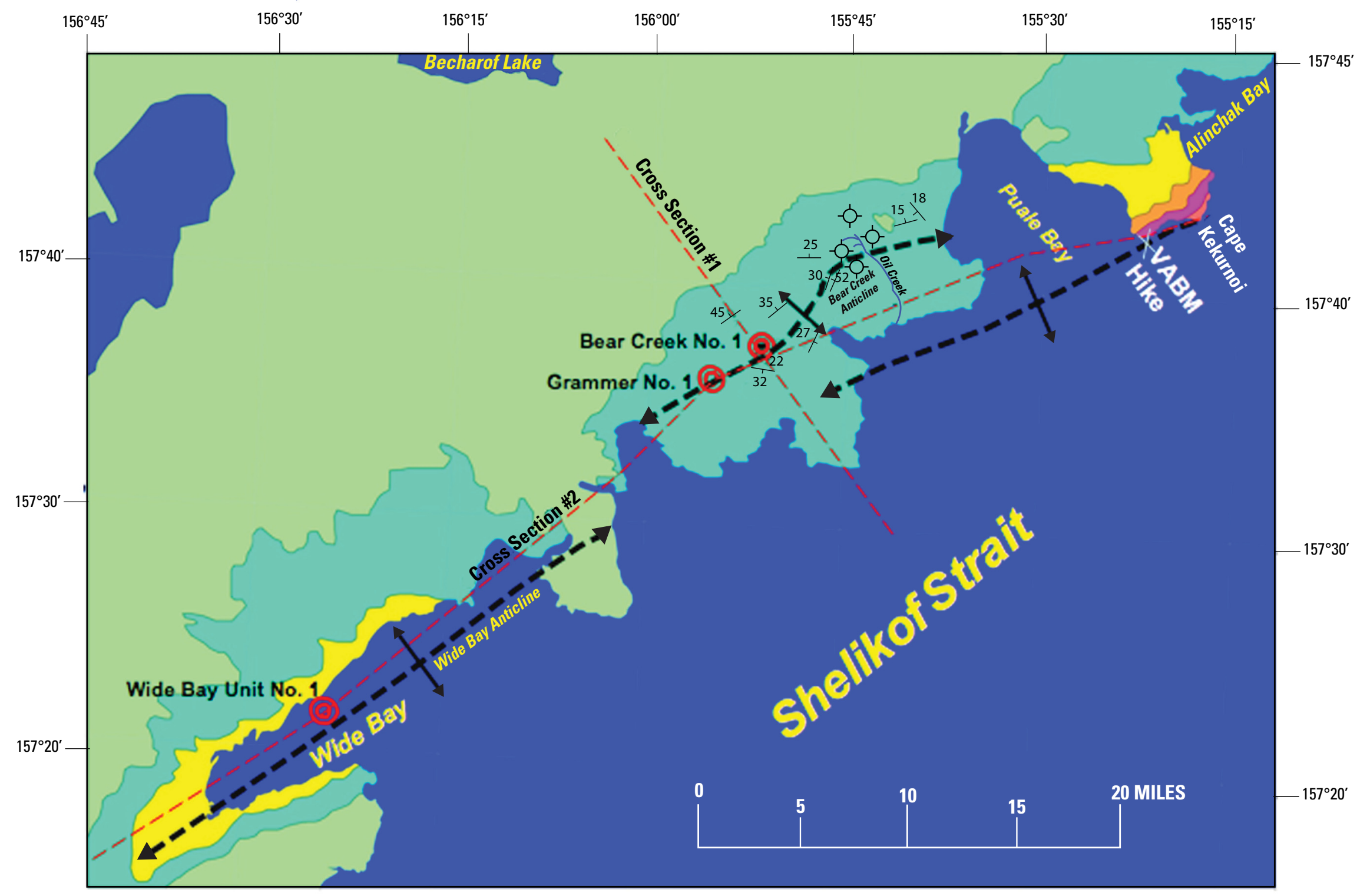

Figure 1. Cape Kekurnoi-Wide Bay index map, showing locations of three oil and gas exploration wells (Humble Oil \& Refining Co.'s Bear Creek No. 1, Standard Oil Co. of California's Grammer No. 1, and Richfield Oil Corp.'s Wide Bay Unit No. 1) drilled in study area, and lines of cross sections 1 and 2 detailed in figures 4 through 5. Strike-and-dip symbols (numbers are dip inclinations, in degrees) denote places where attitude of beds was determined by aerial-photographic analysis with a digital elevation model. Crossed circles, shallow oil wells drilled in early 1900s. Same color codes as in figure 4. 
surface anticline (Bear Creek anticline), motivated its acquisition of a substantial leasehold position across the study area in the late 1950s (H. Mann, written commun., 2007).

The summer 1955 and 1956 field seasons were marked by a major exploration effort by the Humble Oil \& Refining Co., partially led by Bernold M. ("Bruno") Hanson. The research aim of Humble's field program again focused on the oil and gas potential of the Upper Triassic carbonates exposed between Puale and Alinchak Bays (fig. 1; Moon and Hanson, 1956). The Humble field party also visited other Triassic outcrops along the east and west side of lower Cook Inlet, where they measured sections north of Lake Iliamna; at Contact Point, Bruin Bay, and Ursus Cove; and on the east side of the Cook Inlet near Port Graham. The stratigraphic cross sections that they constructed illustrate the widespread occurrence of Upper Triassic carbonate-dominated rocks across the Alaska Peninsula and lower Cook Inlet region.

The presence of Permian strata underlying thick Upper Triassic carbonates cropping out near Puale Bay (fig. 1) was first documented by Hanson (1957). These strata are the oldest exposed rocks of the Chignik subterrane of the Peninsular terrane. Hanson noted that fossiliferous Permian limestone appeared to be interbedded with volcanic breccia (agglomerate) and basaltic flows exposed on adjacent islands to the south. He also noted that agglomerate and associated sandstone (which he tentatively dated as Permian?) occur in seacliffs slightly west of Cape Kekurnoi and are separated from the overlying Triassic carbonates by an angular unconformity (fig. 2).

Humble Oil \& Refining Co.'s work in the late 1950s resulted in the farm-in from the Shell Oil Co. of a large acreage position along the Bear Creek anticline and culminated in the drilling of 14,375 ft (4,382 m)-deep Bear Creek No. 1 well during 1958 and winter 1959. Like the Grammer No. 1 well before it, Bear Creek No. 1 well penetrated numerous hydrocarbon shows between the surface and a depth of 8,200 ft $(2,500 \mathrm{~m})$, but no commercial production was obtained. Drillstem testing of five separate intervals flowed small volumes of gas to the surface. One test in the depth interval 6,080-6,200 $\mathrm{ft}(1,853-1,890 \mathrm{~m})$, flowed gas at rates as high as 750,000 $\mathrm{ft}^{3}$ $\left(21,240 \mathrm{~m}^{3}\right)$ per day, along with the recovery of a large volume of saltwater. Despite numerous showings of live oil from the cuttings, only one of the drillstem-tested depth intervals, $5,768-5,793 \mathrm{ft}(1,758-1,766 \mathrm{~m})$, recovered a show of oil (229 $\mathrm{ft}[69.8 \mathrm{~m}]$ of oil-and-gas-cut mud).

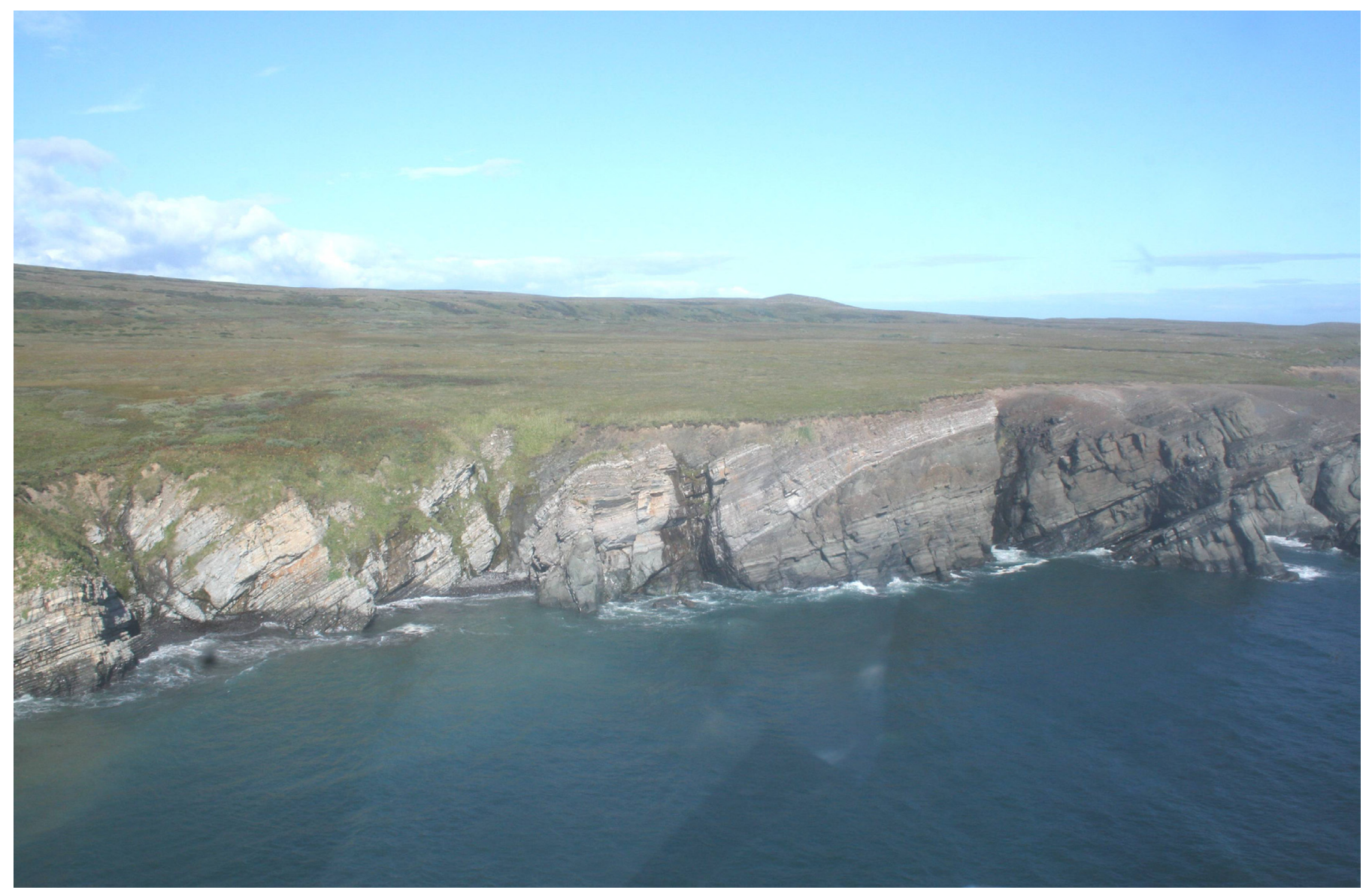

Figure 2. Outcrop of Upper Triassic carbonates of the Kamishak Formation (light-colored rocks) 1.3 mi (2.1 km) west of Cape Kekurnoi (fig. 1), showing lower contact with underlying Permian volcanic agglomerate and volcaniclastic rocks (dark strata). Contact is an angular unconformity with strikingly obvious erosional cutoff of underlying bedded Permian rocks. 
Humble Oil \& Refining Co. geologists believed that neither Bear Creek No. 1 well nor Grammer No. 1 well penetrated any Triassic strata correlative with the carbonate section exposed at Puale Bay (fig. 1), and they tentatively determined that Bear Creek No. 1 well was in a dark volcaniclastic (sandstone) sequence of Triassic age when it reached its total depth of 14,375 ft (4,382 m) (H. Mann, written commun., 2007). As a likely consequence of these interpretations, both Humble and Shell abandoned oil and gas exploration along the Alaska Peninsula and began to refocus their efforts in the interior basins and along the Alaskan North Slope.

In 1963, Richfield Oil Corp., which also recognized the presence and petroleum potential of the Permian and Triassic carbonates exposed at Puale Bay, drilled a 12,568-ft (3,830 m)deep exploratory well, Wide Bay Unit No. 1 (fig. 1), in the Wide Bay anticline, with the goal of evaluating these rocks (G. Mull, written commun., 2007). No carbonates were penetrated in this well, and Richfield let its lease position expire without further drilling in the area. Wide Bay Unit No. 1 well was the last Mesozoic exploratory well drilled in the Puale/Wide Bay area.

Major discrepancies in subsurface correlations involving the Upper Triassic carbonates and underlying Paleozoic basement rocks penetrated in oil-and-gas-exploration wells drilled in the study area (fig. 1) also exist in the literature. The top of the Triassic section was placed by several previous workers (Detterman, 1990; Molenaar, 1996) near the bottom of Humble Oil \& Refining Co.'s Bear Creek No. 1 well $(14,375 \mathrm{ft}$ [4,382 m] deep), and near the bottom of Standard Oil Co. of California's Grammer No. 1 well (7,596 ft [2,315 $\mathrm{m}$ ] deep) only a few miles away, both located along the axis of the Bear Creek anticline. The top of the Triassic section was also reported near the bottom of Richfield Oil Corp.'s Wide Bay Unit No. 1 well (12,566 ft [3,830 m] deep), drilled along the north flank of the Wide Bay anticline (fig. 1). The magnitude of the inferred structural relief between these relative closely spaced wells, $20 \mathrm{mi}(32 \mathrm{~km})$ southwest of the Puale Bay outcrops, indicates major structural and (or) stratigraphic complexity. Therefore, we decided to reexamine not only the original well reports but also the core, ditch-cutting, and (or) electrical-log data from these wells, in an attempt to more rigorously constraint the subsurface stratigraphy and better characterize the Permian-Triassic boundary away from the Puale Bay outcrops.

\section{Stratigraphic Framework of Permian and Triassic Rocks of the Alaska Peninsula and Cook Inlet}

\section{Introduction}

Upper Triassic (Norian) rocks, notably represented by limestone, are widely distributed across much of the Peninsular terrane (Stanton and Martin, 1905; Martin and Katz,
1912; Martin, 1915, 1916, 1921, 1926; Capps, 1923; Smith and Baker, 1924; Smith, 1925, 1926; Detterman and Hartsock, 1966; Stanley, 1979; Detterman and Reed, 1980; Kelley, 1980; Newton, 1983a, b, 1990; Wang, 1986; Wang and others, 1988; Detterman and others, 1996). The name "Kamishak Formation" (originally proposed as "Kamishak Chert" by Martin and Katz, 1912, and subsequently changed to "Kamishak Formation" by Kellum, 1945) is now applied to nearly all exposures of Late Triassic carbonates on the Alaska Peninsula and in the lower Cook Inlet region (fig. 1). We note that outcrops of the Kamishak Formation occur on both sides of the Bruin Bay Fault. Those exposures on its west side (that is, Kamishak Bay) belong to the Iliamna subterrane, where they are structurally complex and overmature in terms of oil and gas potential, whereas those exposures on its east side (notably Puale Bay) are included in the Chignik subterrane, where they are only weakly to moderately folded and well within the thermal range of oil and gas generation.

\section{Thickness}

Thicknesses reported for the Kamishak Formation vary considerably throughout its exposures. Detterman and Hartsock (1966) calculated the thickness of the Upper Triassic section to range from 160 to $1,300 \mathrm{ft}(48.8-396 \mathrm{~m})$ in the Iniskin Peninsula-Tuxedni Bay area in lower Cook Inlet. A detailed measured section of the Kamishak Formation at Puale Bay by Robert M. Egbert in 1979 was designated as a reference section for the formation by Detterman and others (1996); the thickness there was indicated to be $2,623 \mathrm{ft}$ (799.5 m). The definition of a type section or type area was vague as given by Martin and Katz (1912, p. 47), who stated that the unit “**** is typically exposed on the west shore of Kamishak Bay, especially in the vicinity of Bruin Bay." They also made considerable reference to exposures of the same unit at Ursus Cove. In terms of a total thickness for the unit, Martin and Katz (p. 48) stated: "the total thickness of the formation is not known, the beds being so disturbed that no accurate measurement could be made. At Ursus Cove the thickness probably exceeds 2,000 feet $[610 \mathrm{~m}]$ and may be much greater."

Detterman and Reed (1980) discussed the Kamishak Formation in detail on the basis of its exposures in the Iliamna 1:250,000-scale quadrangle. They revised the formation and subdivided it into three members, in ascending order: the Bruin Limestone Member, 2,001 ft (610 m) thick north of Meadow Lake, with a composite thickness at Bruin Bay of $1,804 \mathrm{ft}(550 \mathrm{~m})$; a middle member with a composite thickness of 1,739 ft (530 m) measured from exposures between Kirschner Lake and Iliamna Bay; and the Ursus Member, with a composite thickness of $492 \mathrm{ft}(150 \mathrm{~m})$ measured from exposures between Kirschner Lake and Iliamna Bay.

Upper Triassic limestone and tuff, age equivalents of the Kamishak Formation on the Alaska Peninsula, are also recognized at the southwest end of the Kenai Peninsula near Port Graham. Martin (1915, p. 55-59) discussed a unit he referred to as the "Upper Triassic limestone and tuff," which he noted 
as being exposed only in the vicinity of Port Graham and Dog Salmon (now known as Koyuktolik) Bay. He also noted (p. 55): "The Upper Triassic limestone includes considerable amounts of chert and fine-grained volcanic material, mostly tuffaceous. The thickness of these beds and their stratigraphic relations to the beds that underlie and overlie them are not certainly known." No exact thickness was estimated for the unit, but at one point (p. 57) he refers to a section of limestone $\sim 550 \mathrm{ft}$ (168 m) thick. Two separate faunal horizons were recognized: an older horizon containing Halobia superba Mojsisovics (a bivalve), which now be taken to indicate a Carnian age (older than any of the strata exposed at Puale Bay); and a younger (late Norian) horizon containing Monotis subcircularis Gabb (also a bivalve), which is the same fossil that typifies the upper, greater part of the Kamishak Formation at Puale Bay. Silberling and others (1997) reexamined the halobiids from older USGS collections at Port Graham and determined them to represent two middle Norian age species, $H$. lineata and $H$. dilitata, rather than $H$. superba. This reassignment indicates that the lower faunal horizon is middle Norian.

In his study of Lower Jurassic volcaniclastic rocks of the southwestern Kenai Peninsula, Kelley (1980) discussed the Upper Triassic limestones of the Port Graham area, for which he suggested the informal name "Port Graham Formation." He noted that impure limestone characterizes the unit but that other rock types, such as fine-grained clastic rocks, volcaniclastic rocks, and chert, are also present. Kelley (p. 21) considered the thickness of the Port Graham Formation to be uncertain, its measurement precluded by faulting, absence of marker beds, and inadequate exposure; however, he noted that $4,921 \mathrm{ft}$ $(1,500 \mathrm{~m})$ of the formation was exposed at his designated type section but that this thickness should be considered doubtful because it was determined from a structural interpretation rather than from physical measurement of a continuous section.

The Kamishak Formation of the Chignik subterrane is best exposed northeast of Becharof Lake, along the coast of Shelikof Strait, between Puale and Alinchak Bays (fig. 1), where the exposed Upper Triassic strata were referred to as unnamed Upper Triassic limestone by Stanton and Martin (1905), Martin (1921, 1926), Capps (1923), Smith and Baker (1924), and Smith (1925, 1926). Capps estimated the thickness of this limestone at 1,000 feet (305 m). The first workers to apply the name "Kamishak Formation" to the Upper Triassic beds at Puale Bay were Detterman and others (1996).

\section{Lithology}

The lithology of the lower part of the Upper Triassic Kamishak Formation at Puale Bay (fig. 1) is typified by lightgray to tan biostromal wackestone and packstone with abundant colonial scleractinian corals, brachiopods, bivalves, and gastropods. Some outcrops are pervasively dolomitized, vuggy, and fractured, with localized intensely brecciated intervals reminiscent of solution collapse and (or) hydrothermal alteration (Sralla and Blodgett, 2007). The total thickness of the massive, shallow-water biostromal interval was not determined because some of this interval is apparently offshore, although its thickness was estimated by Smith (1926) to be at least $100 \mathrm{ft}$ (30 m). In 2006, the second author estimated a maximum thickness of $230 \mathrm{ft}(70 \mathrm{~m})$ for the biostromal interval.

The massive biostromal, coralline carbonates transition upward into dark-brown, thin-bedded, nodular lime mudstone. Above this transition, the upper nine-tenths of the Kamishak Formation grades into gray to dark-brown, thin-bedded argillaceous limestone and silty calcareous shale, locally rich in calcispheres. Many bedding planes in the upper part of the formation display an abundance of the late Norian index fossil Monotis (Pacimonotis) subcircularis Gabb, specimens of which have long been noted for their abundance at Puale Bay (fig. 1) and have been illustrated several times from this locality (for example, Fischer, 1875, who identified the bivalve as Monotis salinaria Bronn; Martin, 1916, pl. 29, fig. 1; Silberling and others, 1997, pl. 2, figs. 8-13). The Monotis-bearing beds also commonly contain the spherical floating hydrozoan Heterastridium. The basaltic dikes, sills, and possible flows that have been reported in a few localities were dated at 197£12.0 Ma by Wilson and Shew (1992).

The lower part of the Kamishak Formation was deposited in a backarc, shallow-water, tropical environment, and the rest documents a transgressive sequence interpreted to represent a major eustatic sea-level rise in the later Norian. Wang (1987) summarized the deposition of the Kamishak Formation and subsequent alteration of the original depositional fabric in four stages: (1) buildup of a carbonate platform in a subsiding backarc basin, followed by (2) subaerial exposure leading to the formation of dissolution vugs, caverns, and collapse breccia, (3) a full cycle of sea-level rise and fall accompanied by partial dolomitization of the original lime mud, and (4) a final high-magnitude sea-level rise that drowned the carbonate platform, leading to deposition of the gray to dark-brown, thin-bedded muddy limestone and organic shale characteristic of the upper nine-tenths of the Kamishak Formation.

\section{Stratigraphy}

The Upper Triassic Kamishak Formation unconformably overlies an unnamed Permian section of volcanic agglomerate, volcaniclastic sandstone, and fossiliferous limestone. Permian limestone crops out on a small island $1.27 \mathrm{mi}(2.05 \mathrm{~km}) \mathrm{S} .25^{\circ}$ W. of VABM Hike at the southeast entrance to Puale Bay (fig. 1). The strata exposed on the island consist of $\sim 35 \mathrm{ft}(11 \mathrm{~m})$ of tan-gray, gray-brown-weathering, thick-bedded mediumcrystalline limestone (Hanson, 1957). The company report by Jeffords (1957) reported on and illustrated the diverse fauna from this limestone, including the rugosans Lophophyllidium n.spp., tachylasmid corals, and Verbeekiella n.sp.; the brachiopods Phricodothyris guadalupensis (Shumard), "Spirifer" sulcifer Shumard, Stenoscisma ventusa (Girty), Composita sp., Buxtonia? sp., Wellerella? sp., and unidentified productids; rare bryozoans (unidentified fragments); lithistid(?) sponge spicules; indeterminate ostracodes; and foraminifers represented by one or more species of Ammodiscus, 
Ammovertella, Glomospira?, and Nodosinella?. Jeffords also noted the absence of fusulines in the samples. He considered the brachiopods Phricodothyris guadalupensis, "Spirifer" sulcifer, and Stenoscisma ventusa and the corals Lophophyllidium n.spp. and Verbeekiella n.sp. as indicative of a Middle Permian, most probably early Guadalupian age. The abovementioned age-indicative faunal elements were listed, but not illustrated, in the report by Hanson.

The Humble Oil \& Refining Co. field party also visited islands farther south of the Permian limestone outcrop, where they described dark-green to black, massive volcanic breccia, agglomerate, and basaltic flows (Hanson, 1957) nearly identical to the orange- through dark-green- to black-weathering volcanic agglomerate and sandstone exposed in the seacliffs at Cape Kekurnoi beneath the unconformity (figs. 1, 2).

\section{Documentation of the Unconformity Between Permian and Triassic Strata at Cape Kekurnoi}

The exposures near the southeast entrance to Puale Bay (fig. 1) are the only localities along the Alaska Peninsula where Paleozoic rocks crop out. Therefore, in September 2006, the second author constructed a photographic record by helicopter of much of the seacoast from the mouth of Puale Bay, past Cape Kekurnoi, toward Alinchak Bay for the purpose of better documenting the relation between the Paleozoic and overlying Triassic rocks. About $1.3 \mathrm{mi}(2.1 \mathrm{~km})$ west of Cape Kekurnoi, volcanic agglomerate and dark, thin-bedded volcaniclastic rocks, similar to those described by Hanson (1957), are separated from the overlying Upper Triassic lightgray to tan, thin-bedded carbonates by a conspicuous angular unconformity (fig. 2) near lat $57^{\circ} 43.536^{\prime}$ N., long $155^{\circ} 20.113^{\prime}$ W. (NAD 27 datum). An internal Humble Oil \& Refining Co. field report contains photographs of this unconformity, but its location was omitted by Hanson. A likely result of this omission is that subsequent reports, notably those by Detterman and others $(1983,1987,1996)$, fail to describe or note this beautifully exposed unconformity, and it is not shown on geologic maps of the Puale Bay area.

Several oil-and-gas-exploration wells were drilled deep enough to penetrate the Permian and Triassic section; however, no Permian basement rocks or Upper Triassic from any of these wells have previously been described in the literature.

\section{Discussion of Newly Interpreted Subsurface Data}

\section{Introduction}

The angular unconformity separating Permian and Triassic strata at Puale Bay (figs. 1,2) appears to represent a major, regionally widespread diastrophic event. This unconformity separates the overlying Upper Triassic Kamishak Formation from underlying Paleozoic basement rocks in two oil-andgas-exploration wells drilled farther southwest in the study area-Humble Oil \& Refining Co.'s Bear Creek No. 1 well and Standard Oil Co. of California's Grammer No. 1 wellboth of which penetrated a thick succession of Late Triassic sedimentary rocks of the Kamishak Formation.

\section{Bear Creek No. 1 Well}

In Humble Oil \& Refining Co.'s Bear Creek No. 1 well (figs. 1, 2), the top of the Kamishak Formation is interpreted to be at a depth of 5,000 ft $(1,524)$ and to extend downhole to a depth of $\sim 6,600 \mathrm{ft}(2,012 \mathrm{~m})$ (fig. 3). From the top of the formation to a depth of $5,905 \mathrm{ft}(1,800 \mathrm{~m})$, the lithology is typified in ditch cuttings by gray to dark-brown, calcareous silty shale, with a greater fraction of dark-brown argillaceous silty limestone at increasing depth. The limestone content further increases below a depth of 5,905 ft $(1,800 \mathrm{~m})$ and then quickly transitions at a depth of $6,080 \mathrm{ft}(1,853 \mathrm{~m})$ into light-gray microcrystalline dolomite with scattered varicolored igneous material (dikes?). Even though no megafossils were obtained from small cuttings, the overall lithology in the depth interval $5,000-5,905 \mathrm{ft}(1,524-1,800 \mathrm{~m})$ closely matches that of the upper part of the Kamishak Formation exposed at Puale Bay. In fact, when samples from outcrops of the Kamishak Formation were compared side by side with well cuttings under a binocular microscope, they appeared to be nearly identical. Nowhere have we observed such an abundance of carbonates in any of the overlying Jurassic rocks. Both the stratigraphic sequence and the lithology support our interpretation that the Bear Creek No. 1 well penetrated a thick section of the Triassic Kamishak Formation.

Indirect support of this interpretation was provided by Rock Eval pyrolysis data (Threlkeld and others, 2000). Subsurface total organic-carbon (TOC) contents through the interpreted Kamishak Formation interval range from 0.62 to 1.5 weight percent and average 0.91 weight percent. The hydrogen index averages $243 \mathrm{mg} \mathrm{S} 2 / \mathrm{g}$ TOC, but a maximum of $424 \mathrm{mg} \mathrm{S} 2 / \mathrm{g}$ TOC (highly oil prone) was obtained near the top of the Kamishak Formation, at a depth of 5,000 $\mathrm{ft}(1,524$ $\mathrm{m})$. These TOC contents and hydrogen-index values signify an oil-and-gas-prone source rock with fair to good generative potential, although only marginal maturity $\left(R_{0}=0.51\right)$ at best is achieved in Bear Creek No. 1 well. All the Jurassic rocks that crop out in the study area (fig. 1), except the Kialagvik Formation, are known to have very low TOC contents, with mostly inert kerogen.

We conclusively rule out interpretation of a Middle Jurassic age for the depth interval 5,000-6,601 ft (1,524-2,012 m) on the basis of a lithology unlike that known in the Kialagvik Formation at Puale Bay (fig. 1). Instead, a lithology and TOC content consistent with the Kialagvik Formation occur uphole at a depth of $\sim 1,968 \mathrm{ft}(600 \mathrm{~m})$, where TOC contents range from 0.79 to 2.2 weight percent, and average 1.2 weight percent and hydrogen index averages $328 \mathrm{mg} \mathrm{S2} / \mathrm{g}$ TOC, indicative of a good type II oil-prone source rock. 
The dolomitic depth interval 6,079-6,601 ft (1,853-2,012 $\mathrm{m}$ ) is anomalous in comparison with any part of the Kamishak Formation cropping out at Puale Bay (fig. 1). Although the section has open-hole electrical-log characteristics indicating fair porosity and good permeability, it is notably devoid of bivalves or coral fragments and has a different texture and color from those of the fossiliferous lower part of the
Kamishak Formation cropping out west of Cape Kekurnoi. Although these depth intervals may be time-stratigraphically correlative, they represent a different facies and depositional environment. As a result, we speculate that the muddy, microcrystalline dolomites observed in Bear Creek No. 1 well in the depth interval 6,079-6,601 ft (1,853-2,012 m) indicate a very low energy, restricted lagoonal environment, separated

\section{DEPTH}

IN FEET

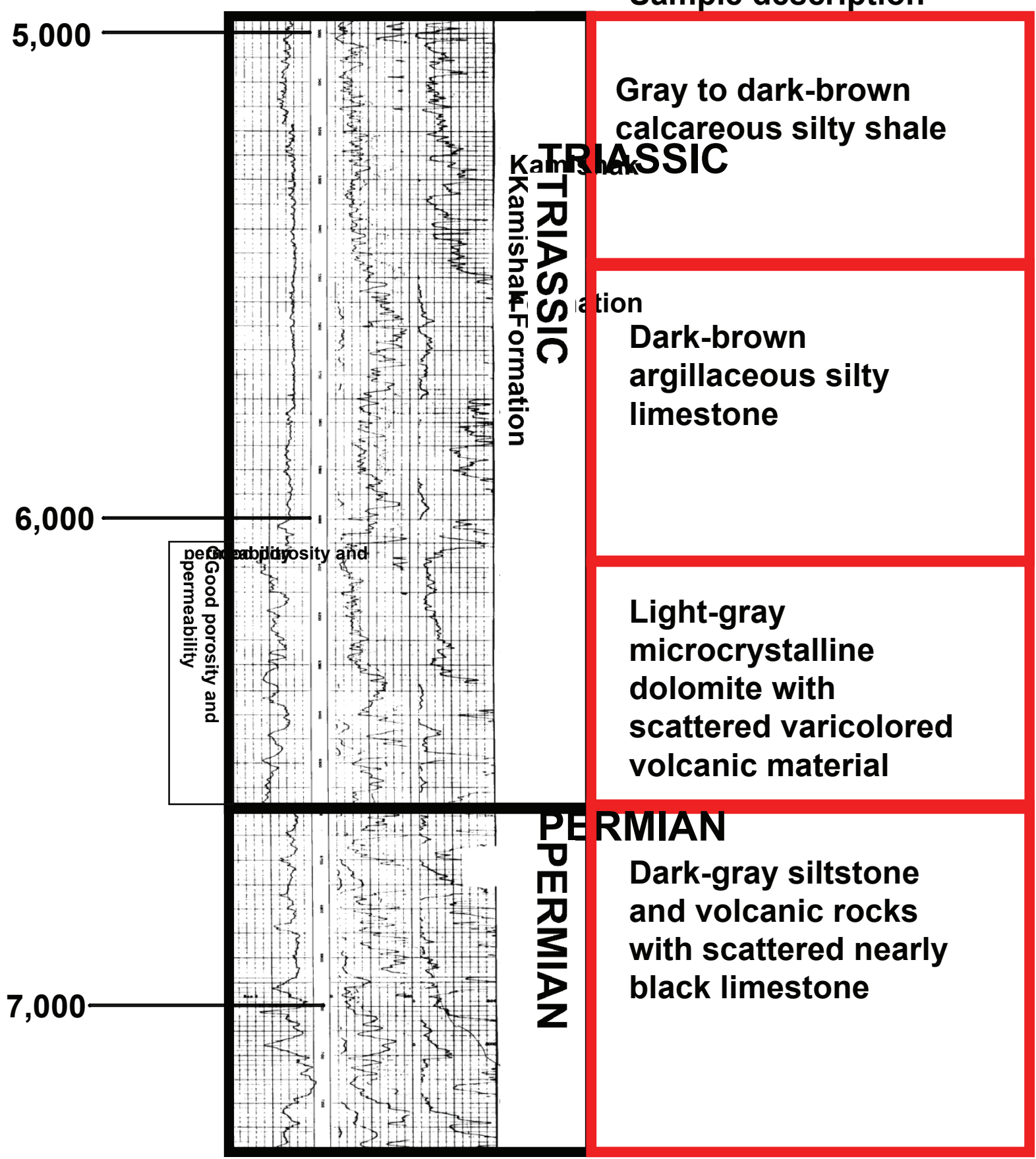

Figure 3. Open-hole electrical log of Humble Oil \& Refining Co.'s Bear Creek No. 1 well, showing interpreted position of the Upper Kamishak Formation and zone of good porosity and permeability at its base. 
from open-marine circulation by the higher-energy, biostromal carbonate observed at Puale Bay.

Below a depth of $6,600 \mathrm{ft}(2,012 \mathrm{~m})$, the lithology

quickly grades back to dark-gray siltstone and volcanic rocks with scattered, nearly black limestone. By a depth of 8,000 ft $(2,438 \mathrm{~m})$, the lithology consists of very dark gray to nearly black, volcanically derived granule conglomerate and tuff and nearly black limestone. A core chip from a depth of 9,400 ft $(2,865 \mathrm{~m})$ consists of dark-gray limestone containing small echinoderm fragments suggestive of a late Paleozoic age.

\section{Grammer No. 1 Well}

Standard Oil Co. of California's Grammer No. 1 well, drilled in the valley of Salmon Creek (fig. 1), was spudded in the Shelikof Formation on July 17, 1938, and abandoned on March 8, 1940. The well, which attained a total depth of 7,596 $\mathrm{ft}(2,315 \mathrm{~m})$, at that time was deepest well drilled in Alaska. According to the limited megafossil data identified by G.D. Hanna in the Tide Water Associated Oil Co. internal company report by Hewitt (1940), a Grammoceras fauna (Grammoceras is an ammonite) characteristic of the Kialagvik Formation was obtained in the depth interval 2,116-2,140 ft (645-652 m). A few scattered small pectens, brachiopods, unidentified ammonites, and plant remains were reported throughout the depth interval 2,140-2,820 ft (652-860 m). Abundant ammonites identified by Hanna as belonging to the Early Jurassic genus Arietites were obtained in the depth interval 2,820-2,924 ft (860-891 m), indicating that it corresponds to the Lower Jurassic Bidarka Formation of Kellum (1945), which is partly correlative with the Talkeetna Formation as recognized by Detterman and others (1996) in the Puale Bay area (fig. 1). Fossils obtained lower in the well included a few small undiagnostic pectens (but still reported in the lithologic $\log$ as similar to those obtained from Jurassic rocks of the region) in the depth interval 3,724-3,730 ft (1,135-1,137 $\mathrm{m})$ and a few small bivalves at a depth of 4,224 ft (1,287 m) identified by Hanna as belonging to the long-ranging genus Avicula. Although he believed the specimens of Avicula to not be age diagnostic, he noted that they were similar to forms occurring elsewhere in the Lower Jurassic. These specimens were reported to be deposited in the California Academy of Sciences in San Francisco, but at an inquiry made to the curator of the paleontologic collections indicate that specimens from these depths are absent in their collections.

The absence of age-diagnostic fossils and open-hole electrical-log data somewhat hinders identification of the stratigraphic units penetrated at depth in Grammer No. 1 well. We tentatively place the upper contact between the Upper Triassic Kamishak Formation and the overlying Lower Jurassic section in the depth interval 3,730-4,224 ft (1,137-1,287 m) on the basis of lithologic transitions from dominantly sandstone, characteristic of the Lower Jurassic, into more abundant calcareous shale and limestone more typical of the Kamishak Formation at Puale Bay (fig.1). We tentatively place the base of the Kamishak Formation at 4,790 ft (1,460 m) depth. The basal part of our Kamishak section here also bears lightcolored dolostone, similar to what we note in Humble Oil \& Refining Co.'s Bear Creek No. 1 well and in outcrop at the southeast entrance to Puale Bay. Although the lower contact of the Kamishak Formation is not easily interpretable from the limited data on hand, the well evidently penetrated older (probable Paleozoic) basement rocks, as shown by the increasing abundance of highly tuffaceous beds downhole below our interpreted base for the Kamishak Formation. Slate was finally observed near the bottom of the well.

\section{Wide Bay Unit No. 1 Well}

Richfield Oil Corp.'s Wide Bay Unit No. 1 well, farther southwest in the study area (fig. 1), penetrated dark, probable Paleozoic volcanic agglomerate and greenstone in the depth interval 8,819-12,566 ft (2,699-3,830 m), after first penetrating the Middle Jurassic Kialagvik Formation and, later, part of the Lower Jurassic Bidarka Formation of Kellum (1945) (equivalent to the Talkeetna Formation of Detterman and others, 1996, as used by them for the Puale Bay area) from the surface to a depth of 2,300 ft (701 m). The entire Upper Triassic Kamishak Formation is absent, owing to either a major unconformity or faulting. The upper 2,300 ft (701 m) of the well consists of nearly flat lying sedimentary rocks of Early and Middle Jurassic age.

The oldest authentic megafossils from this well, which were obtained from core 5 in the depth interval 2,235-2,236 $\mathrm{ft}(681.2-681.5 \mathrm{~m})$, consisted of abundant specimens of the ammonite Waehneroceras cf. W. portlocki (Wright), indicative of a middle Hettangian (early Early Jurassic) age (Imlay, 1981, p. 12, 30). Radiolarians were also recovered from 100-ft (30.5 m) intervals of ditch cuttings from the depth interval 100-2,300 $\mathrm{ft}(30.5-701 \mathrm{~m})$. These fossils were illustrated without taxonomic identification in an anonymous 37-page report entitled "Richfield Oil Company Wide Bay Unit \#1-Scanning Electron Micrographs of Selected Radiolarians" that was donated to the Alaska Geological Material Center in Eagle River, Alaska, and cataloged as Geologic Materials Center Data Report No. 53B. We are presently trying to find a Mesozoic radiolarian specialist to identify the illustrated fossils.

The marked increase in dip $\left(60-70^{\circ}\right)$ that was observed in core 6 from the depth interval 3,406-3,411 ft (1,038-1,040 $\mathrm{m})$, together with the higher induration associated with the siliceous mudstones in this interval, suggests that either an unconformity or a fault separates the interval between cores 5 and 6. Again, as noted above, no lithologic equivalent of limestone of the Kamishak Formation was observed in the cuttings and core, and so we presume that such an equivalent is absent in Wide Bay Unit No. 1 well. Below core 6, the well penetrated a thick succession of siliceous mudstone and finally, in the lower third, a succession of dominantly dark-greenishgray to nearly black greenstone and volcanic agglomerate. The much more highly indurated lithologic succession below a depth of 2,300 ft (701 m) is considered to be of probable late Paleozoic age. This interpretation is supported by the presence 
of echinoderm fragments of late Paleozoic morphotype in a thin section of chert-granule sandstone from core 16 in the depth interval 7,728-7,734 ft (2,355-2,357 m). We recognized no Upper Triassic rocks in Wide Bay Unit No. 1 well.

\section{Ramifications for Future Petroleum Exploration on the Alaska Peninsula and in Cook Inlet}

The broad, elongate anticlines at Bear Creek, Puale Bay, and Wide Bay (fig. 1) document the most significant episode of structural deformation in the region. A geometrically balanced structural cross section through Bear Creek anticline, utilizing the newly interpreted subsurface stratigraphic information discussed here, invokes fault-bend folding that accommodates moderate amounts of shortening (fig. 4). This new interpretation differs significantly from previous suggestions of extremely intense structural deformation inferred from the widely varying subsurface stratigraphic calls reported by Detterman and others (1996). Our hypothesis suggests that large-scale folding along the Alaska Peninsula is broad enough to preclude multiple levels of structural detachment above the Permian and Triassic rocks, such that some structural traps may be relatively simple and cover large areas.

The presence of the spectacular angular unconformity documented west of Cape Kekurnoi (fig. 2), separating the Upper Triassic Kamishak Formation from underlying Permian limestone and volcanic agglomerate, has additional exploration ramifications. Subaerial exposure of Permian strata at this major unconformity could have allowed meteoric leaching of carbonate-rich units and aided in the formation of secondary solution-enhanced porosity. Areas where Permian limestone intervals directly underlie this unconformity represent areas for specific exploration potential, although exploration challenges may result from the paleotopographic relief along this unconformity. The Upper Triassic Kamishak Formation could locally be absent (for example, in Richfield Oil Corp.'s Wide Bay Unit No. 1 well) in certain areas where substantial paleotopographic highs existed on the Permian-Triassic unconformity surface (fig. 5B). Long-offset, high-fold, two- and (or) three-dimensional seismic data would be needed to help reduce exploration risk.

Where present, the Upper Triassic carbonates and organic shales hold significant petroleum-exploration potential. Organic-rich beds with TOC contents of 0.62 to 3.8 weight percent in the upper part of the Kamishak Formation represent fair to excellent type II oil-prone hydrocarbon source rocks (Wang, 1987) that remain immature to marginally mature in surface outcrops but are likely mature to overmature in the deep subsurface (Molenaar, 1996).

Locally well developed fracture, vuggy, and grain-moldic porosities, in combination with scattered layers with fair intercrystalline porosity (5-10 percent), were observed in dolomitized parts of the lower biostromal section at Puale Bay (fig. 1). The prevalence of coarse-crystalline saddle dolomite lining vugs and fractures suggests that $\mathrm{Mg}$-rich hydrothermal brines were injected into the host carbonates sometime after deposi-

Bear Creek No. 1

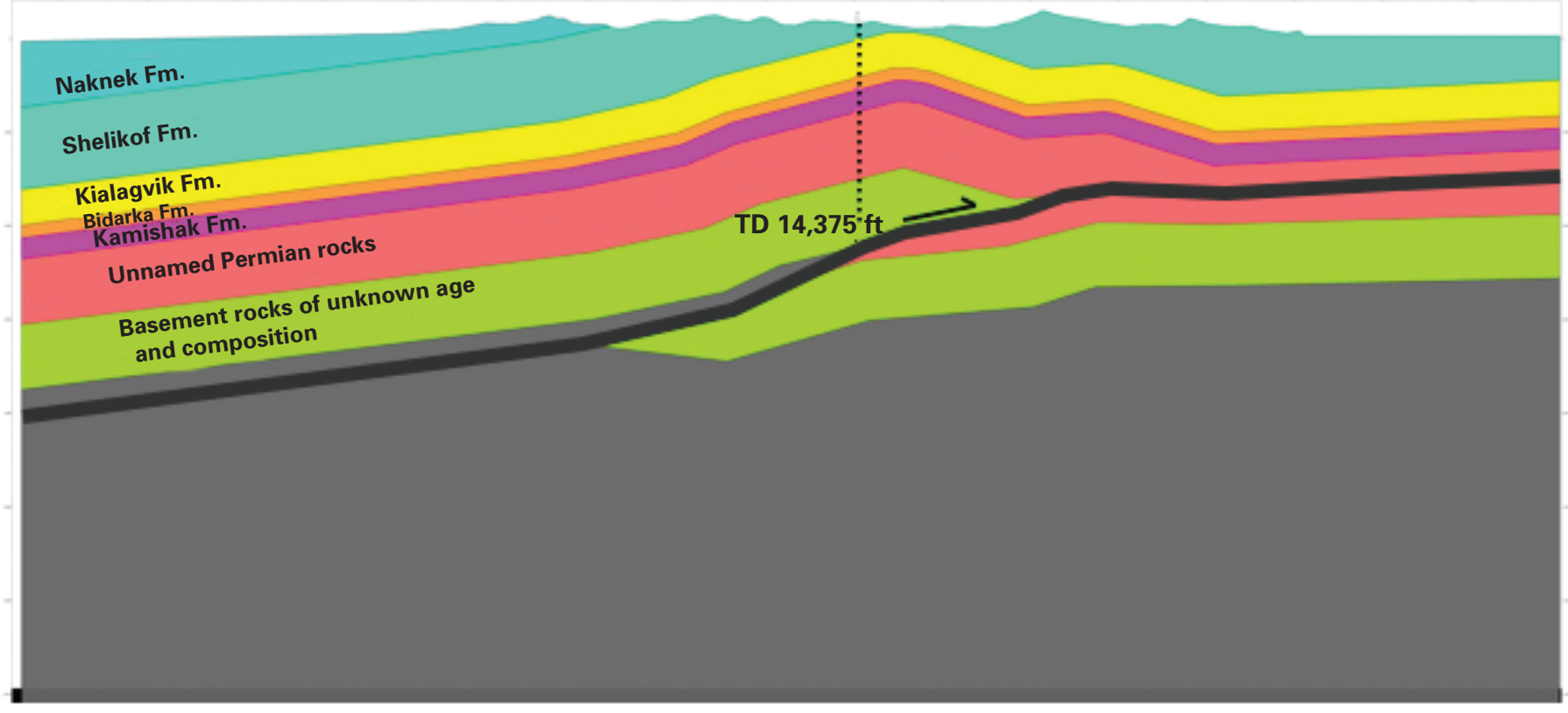

Figure 4. Balanced structural cross section 1 through the Bear Creek anticline (fig. 1). No vertical exaggeration. TD, total depth. 
tion. The combination of these porosity types indicates a good reservoir potential in the Upper Triassic Kamishak Formation (Sralla and Blodgett, 2007).

Favorable porosity and an effective permeability as high as 21.2 mdarcies is indicated by open-hole electrical logs and test data in the depth interval 6,079-6,499 ft (1,853-1,981 m) in Humble Oil \& Refining Co.'s Bear Creek No. 1 well (Sralla and Blodgett, 2007). The abundance of light-gray, fractured, microcrystalline dolomite observed in ditch cuttings from this depth interval suggests a very shallow water, low-energy lagoonal carbonate facies that is a possible time-stratigraphic equivalent of the biostromal facies cropping out west of Cape Kekurnoi, near Puale Bay (fig. 1).

We are not the first workers to suggest oil-and-gasexploration potential in Permian and Triassic carbonates of the study area (fig. 1). Other petroleum-industry entities had earlier (1930s-1950s) recognized the exploration potential of these rocks. Surprisingly, however, except for the report by Molenaar (1995), much of this earlier industry research was never published, and so some or all of it has likely remained unknown to the most recent generation of oil and gas explorers. Therefore, we believe that the Kamishak Formation remains an attractive, underexplored drilling target possibly underlying several of the broad anticlines situated across the Alaska Peninsula and Cook Inlet region. To date, only three wells have been drilled deep enough to explore this depth interval, two of which (Humble Oil \& Refining Co.'s Bear Creek No. 1 and Standard Oil Co. of California's Grammer No. 1) penetrated thick oil-and-gas-charged sections of Triassic carbonate-rich rocks. Even though neither Bear Creek No.

SW

NE

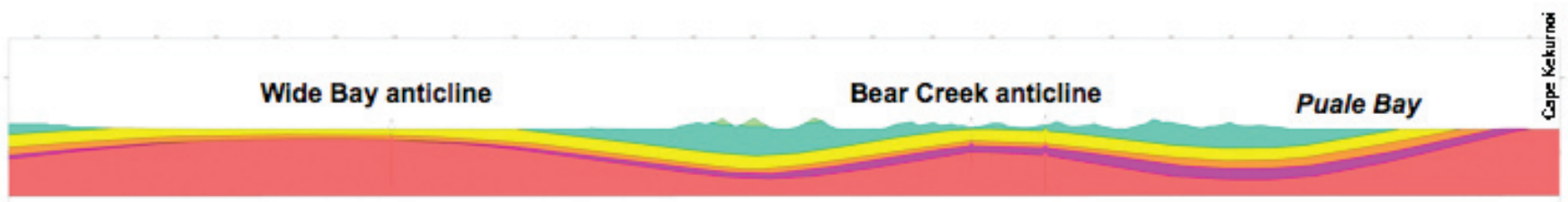

$\boldsymbol{A}$

SW

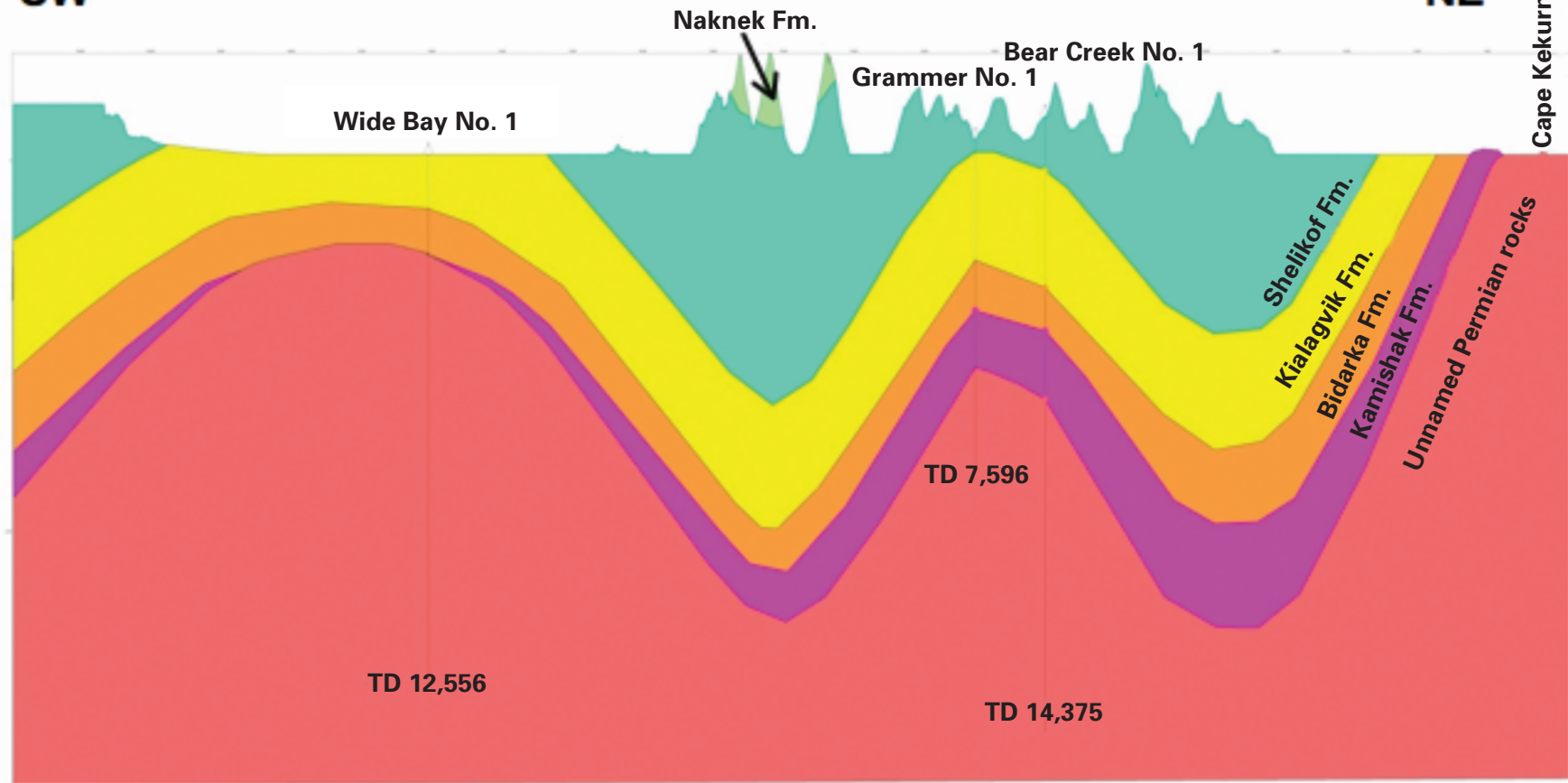

$\boldsymbol{B}$

Figure 5. Cross section 2 from Cape Kekurnoi through the Bear Creek and Wide Bay anticlines (fig. 1). $A$, No vertical exaggeration. $B$, Vertical exaggeration, $10 \times$. 
1 well nor Grammer No. 1 well tested commercial amounts of oil and gas, both wells were drilled in areas where a surface anticline is deeply eroded, possibly allowing a compromise of the trap and seal through communication of faults and fractures with the surface. These conduits to the surface may give rise to the impressive oil and gas seeps at the head of Oil Creek. Future exploration efforts should be concentrated along several of the deeper seated, moderately folded anticlines over much of the Alaska Peninsula extending from Chignik Lagoon, through the Herendeen Bay/Sapsuk Lake area, to the Black Hills and offshore into the Bering Sea. The chance of an effectively sealed, unbreached hydrocarbon accumulation in the Permian and Triassic rocks is higher along these anticlines than elsewhere in the region.

\section{Conclusions}

A major angular unconformity separating carbonates and shales of the Upper Triassic Kamishak Formation from an underlying unnamed sequence of Permian agglomerate, volcaniclastic rocks (sandstone), and limestone is photographically documented near Cape Kekurnoi on the Alaska Peninsula (figs. 1, 2). According to our interpretation of the well logs, cuttings, and core chips, this unconformity was also penetrated in Humble Oil \& Refining Co.'s Bear Creek No. 1 and Standard Oil Co. of California's Grammer No. 1 wells drilled to the southwest near the abandoned town of Kanatak on the Alaska Peninsula. Richfield Oil Corp's Wide Bay Unit No. 1 well, drilled southwest of and structurally on trend with the other two wells, probed deeply into the Paleozoic basement, but Triassic strata are absent, owing to either a major unconformity or a large fault. Our reinterpretation of previously derived subsurface data, in combination with newly acquired field observations, indicates that a major pre-Late Triassic diastrophic event affected rocks of the northern Alaska Peninsula before initial deposition of the regionally widespread Kamishak Formation.

The oil-and-gas-exploration potential of Permian and Triassic rocks of study area (fig. 1) has been recognized by the petroleum industry since at least the 1930s. The Upper Triassic Kamishak Formation includes both significant source- and reservoir-rock potential. The presence of an angular unconformity separating the Upper Triassic Kamishak Formation from underlying Permian limestone and volcanic agglomerate is especially significant because meteoric leaching of carbonate-rich intervals within the Permian section may occur along this unconformity surface. Areas where Permian limestone intervals are truncated directly beneath the unconformity represent targets for specific exploration. The Upper Triassic shallow-water biostromal carbonate buildups and lagoonal-facies equivalents deposited above this unconformity surface are potential hydrocarbon reservoirs but may not occur over all Late Triassic paleotopographic highs. The oil and gas potential of these Permian and Triassic rocks appears to be good but remains untested beneath several broad, deep-seated anticlines along the Alaska Peninsula.

\section{Acknowledgments}

We especially thank James B. Dolman, former president and CEO of Hewitt Mineral Corp. of Ardmore, Okla., who personally encouraged and helped motivate our endeavor to better understand the petroleum geology of the Alaska Peninsula, and remained passionately interested in this work until the time of his death on December 25, 2007.

We thank Sam Egli of Egli Air Haul, King Salmon, Alaska, for his helicopter time and flying expertise along the Alaska Peninsula. We appreciate William ("Bill") Dolman (Ardmore, Okla.) for his capable assistance in the field. We greatly benefited from fruitful discussions on the history of petroleum exploration and geologic investigations of the study area (fig. 1) with the following individuals: Herb Mann (Houston, Tex.), Keith A. Knabe (Houston, Tex.), Gil Mull (Santa Fe, N. Mex.), Mahlon Kirk (Redding, Calif.), Gar Pessel (Fairbanks, Alaska), F.H. ("Ric") Wilson (U.S. Geological Survey, Anchorage, Alaska), Jack Roderick (Anchorage, Alaska) and Les Magoon (U.S. Geological Survey, Menlo Park, Calif.). John W. Reeder of the Alaska Geologic Materials Center in Eagle River graciously provided us with access to core materials from the Alaska Peninsula. We gratefully acknowledge David C. Shafer (Chevron Corp., Anchorage, Alaska), John Larson (Minerals Management Service, Anchorage, Alaska), Helen Gibbons (U.S. Geological Survey, Menlo Park, Calif.), and George A. Havach (U.S. Geological Survey, Menlo Park, Calif.) for their thoughtful reviews of the manuscript. XTO Energy, Inc., of Fort Worth, Tex., permitted the second author to publish the results of his field work.

\section{References Cited}

Capps, S.R., 1923, The Cold Bay district, in Mineral resources of Alaska; report on progress of investigations in 1921: U.S. Geological Survey Bulletin 739, p. 77-116.

Detterman, R.L., 1990, Stratigraphic correlation and interpretation of exploratory wells, Alaska Peninsula: U.S. Geological Survey Open-File Report 90-279, 51 p.

Detterman, R.L., Case, J.E., Miller, J.W., Wilson, F.H., and Yount, M.E., 1996, Stratigraphic framework of the Alaska Peninsula: U.S. Geological Survey Bulletin 1969-A, 74 p.

Detterman, R.L., Case, J.E., Wilson, F.H., and Yount, M.E., 1987, Geologic map of the Ugashik, Bristol Bay, and western of Karluk quadrangles, Alaska: U.S. Geological Survey Miscellaneous Investigations Series Map I-1685, scale $1: 250,000$. 
Detterman, R.L., Case, J.E., Wilson, F.H., Yount, M.E., and Allaway, W.H., Jr., 1983, Geologic map of the Ugashik, Bristol Bay, and western part of Karluk quadrangles, Alaska: U.S. Geological Survey Miscellaneous Field Studies Map MF-1539-A, scale 1:250,000.

Detterman, R. L., and Hartsock, J.K., 1966, Geology of the Iniskin-Tuxedni region, Alaska: U.S. Geological Survey Professional Paper 512, 78 p.

Detterman, R.L., and Reed, B.L., 1980, Stratigraphy, structure, and economic geology of the Iliamna quadrangle, Alaska: U.S. Geological Survey 1368-B, 86 p.

Fischer, P.H., 1875, Sur quelques fossiles de l'Alaska, in Pinard, A.L., Voyages à la côte nord-ouest de l'Amérique executés dans les années 1870-1872: Paris, E. Leroux, pt. 1, p. 33-36.

Hanna, G.D., Leach, C.E., Tallant, R.L., Bryan, J.J., and Scott, E.W., 1937, Preliminary geologic report on the Bear Creek Anticline, Alaska-1937: San Francisco, Calif., Tide Water Associated Oil Co.-Standard Oil Co. of California-Union Oil Co. of California internal report, 20 p.

Hanson, B.M., 1957, Middle Permian limestone on Pacific side of Alaska Peninsula: American Association of Petroleum Geologists Bulletin, v. 41, no. 10, p. 2376-2378.

Hewitt, R.L., 1940, Final geological report on the Standard Oil Company of California, Tide Water Associated Oil Company, and Union Oil of California well, Grammer No. 1: San Francisco, Tide Water Associated Oil Co. internal report, $74 \mathrm{p}$.

Imlay, R.W., 1981, Early Jurassic ammonites from Alaska: U.S. Geological Survey Professional Paper 1148, 49 p.

Jeffords, R.M., 1957, Permian fossils from an island in Puale Bay, Alaska: Houston, Humble Oil \& Refining Co. Geologic Research Report 57-24, 6 p.

Kelley, J.S., 1980, Environments of deposition and petrography of Lower Jurassic volcaniclastic rocks, southwestern Kenai Peninsula, Alaska: Davis, University of California, Ph.D. thesis, 304 p.

Kellum, L.B., 1945, Jurassic stratigraphy of Alaska and petroleum exploration of northwestern America: New York Academy of Sciences Transactions, ser. 2, v. 7, no. 8, p. 201-209.

Martin, G.C., 1915, The western part of Kenai Peninsula, in Martin, G.C., Johnson, B.L., and Grant, U.S., Geology and mineral resources of Kenai Peninsula, Alaska: U.S. Geological Survey Bulletin 587, p. 41-112.

Martin, G.C., 1916, Triassic rocks of Alaska: Geological Society of America Bulletin, v. 27, p. 685-718.
Martin, G.C., 1921, Preliminary report on petroleum in Alaska: U.S. Geological Survey Bulletin 719, 83 p.

Martin, G.C., 1926, The Mesozoic stratigraphy of Alaska: U.S. Geological Survey Bulletin 776, 493 p.

Martin, G.C., and Katz, F.J., 1912, A geologic reconnaissance of the Iliamna region, Alaska: U.S. Geological Survey Bulletin $485,138 \mathrm{p}$.

Molenaar, C.M., 1995, Alaska Peninsula, in Magoon, L.B., Molenaar, C.M., Bruns, T.R., Fisher, M.A., Valin, Z.C., Southern Alaska Province (003), in Gautier, D.L., Dolton, G.L., Takahashi, K.I., and Varnes, K.L., eds., 1995 National assessment of United States oil and gas resources-results, methodology, and supporting data: U.S. Geological Survey Digital Data Series 30, p. 2-4, CD-ROM.

Molenaar, C.M., 1996, Thermal-maturity patterns and geothermal gradients on the Alaska Peninsula, in Johnsson, M.J., and Howell, D.G., eds., Thermal evolution of sedimentary basins in Alaska: U.S. Geological Survey Bulletin 2142, p. 11-19.

Moon, C.G., and Hanson, B.M., 1956, Reconnaissance geology and petroleum possibilities of the Alaska Peninsula: Houston, Tex., Humble Oil \& Refining Co., Exploration Department report, $119 \mathrm{p}$.

Newton, C.R., 1983a, Norian (Late Triassic) mollusks of Cordilleran allochthonous terranes; paleoecology and paleozoogeography: Santa Cruz, University of California, Ph.D. thesis, $173 \mathrm{p}$.

Newton, C.R., 1983b, Paleozoogeographic affinities of Norian bivalves from the Wrangellian, Peninsular, and Alexander terranes, northwestern North America, in Stevens, C.H., ed., Pre-Jurassic rocks in western North American suspect terranes: Society of Economic Paleontologists and Mineralogists Symposium, Pacific Section Convention, Sacramento, Calif., 1983, Proceedings, p. 37-48.

Newton, C.R., 1990, Triassic-Jurassic boundary section at Puale Bay, Alaska Peninsula; comparative diversity patterns of skeletal faunas and trace fossils [abs.]: American Association of Petroleum Geologists Bulletin, v. 74, no. 5, p. 730 .

Silberling, N.J., Grant-Mackie, J.A., and Nichols, K.M., 1997, The Late Triassic bivalve Monotis in accreted terranes of Alaska: U.S. Geological Survey Bulletin 2151, 21 p.

Smith, W.R., 1925, The Cold Bay-Katmai district, in Mineral resources of Alaska; report on progress of investigations in 1923: U.S. Geological Survey Bulletin 773, p. 183-207.

Smith, W.R., 1926, Geology and oil development of the Cold Bay district, in Mineral Resources of Alaska; report on progress of investigations in 1924: U.S. Geological Survey Bulletin 783, p. 63-88. 
Smith, W.R., and Baker, A.A., 1924, The Cold Bay-Chignik district, in Mineral resources of Alaska; report on progress of investigations in 1922: U.S. Geological Survey Bulletin 755, p. 151-218.

Sralla, Bryan, and Blodgett, R.B., 2007, Reservoir potential of Late Triassic Kamishak Formation; Puale Bay, Alaska Peninsula [abs.]: American Association of Petroleum Geologists Annual Convention \& Exhibition, Long Beach, 2007, Abstracts, p. 132.

Stanley, G.D., Jr., 1979, Paleoecology, structure, and distribution of Triassic coral buildups in western North America: University of Kansas Paleontological Contributions, v. 65 , p. $1-58$.

Stanton, T.W., and Martin, G.C., 1905, Mesozoic section on Cook Inlet and Alaska Peninsula: Geological Society of America Bulletin, v. 16, p. 391-410.
Threlkeld, C.N., Obuck, R.C., and Gunther, G.L., 2000, Organic geochemistry data of Alaska: U.S. Geological Survey Digital Data Series DDS-59, CD-ROM

[URL http://energy.cr.usgs.gov/akfinal/].

Wang, J., 1987, Sedimentology of Norian (Late Triassic) cherts and carbonates from the Peninsular terrane: Puale Bay, Alaska Peninsula: Syracuse, N.Y., Syracuse University, M.S. thesis, 124 p.

Wang, J., Newton, C.R., and Dunne, L., 1988, Late Triassic transition from biogenic to arc sedimentation on the Peninsular terrane, Puale Bay, Alaska Peninsula: Geological Society of America Bulletin, v. 100, no. 9, p. 1466-1478.

Wilson, F.H., and Shew, N.B., 1992, Map and tables showing geochronology and whole-rock geochemistry of selected samples; Ugashik and part of Karluk quadrangles, Alaska: U.S. Geological Survey Miscellaneous Field Studies Map MF-1539-E, scale 1:250,000. 